\title{
Beneficiation of Oil Shale by Froth Flotation: Critical Review
}

\author{
S., Al-Thyabat ${ }^{1, *}$, E. Al-Zoubi ${ }^{2}$, H. Alnawafleh ${ }^{1}$ and K. Al-Tarawneh ${ }^{1}$ \\ ${ }^{I}$ Department of Mining Engineering, Al-Hussein Bin Talal University, Jordan \\ ${ }^{2}$ Department of Chemistry - Al-Hussein Bin Talal University, Jordan
}

\begin{abstract}
Oil shale beneficiation by froth flotation hasn't received enough attention in the last two decades. The reason was the economics of the process as well as its environmental impact. However, the recent surge in oil price and recent developments in fine grinding technologies may improve the efficiency of oil shale beneficiation by such process.

In this work, oil shale concentration by froth flotation technique was critically reviewed. It was found that most of the work was conducted by conventional mechanical flotation using non-ionic collector such as kerosene. Flotation has more pronounced effect on flotation of low grade oil shale; Almost 95\% of ash forming minerals were removed to enrich oil shale concentrate by factor of 2-4 with 60-95\% kerogen recovery and approximately 50-300\% increase in oil yield (L/tonne) .Oil shale retorting economics showed that beneficiation reduced the capital cost for pyrolysis and fractionation by $250 \%$ and spent shale disposal by $270 \%$. However, these saving are offset by the cost of beneficiation (grinding, flotation, and dewatering). Therefore, the key for economical oil shale concentration process is the reduction of fine grinding costs.
\end{abstract}

Keywords: Flotation, Oil shale, oil shale beneficiation.

\section{INTRODUCTION}

Oil shales are wide group of sedimentary rocks that contains organic matter of marine, or terrestrial origin [1]. Their organic matter is finely disseminated in the inorganic shale matrix $[2,3]$. They have economic importance since they may be a potential source of energy, including crude oil and gas through conversion their organic matter which called kerogen to synthetic oil or gas $[4,5]$. Kerogen can be converted into oil through retorting/pyrolysis or burned directly as fossil fuel to produce energy. However, not all organic carbon can be converted by retorting, Tsai and Lumpkin [6] reported that only $65 \%$ of organic carbon can be converted to oil by Fisher assay. According to Tippen and Rex [7] oil yield depends on the atomic ratio of hydrogen to carbon in the organic matter.

Kerogen is characterized by its high molecular weight and variable chemical formula. The main elements in kerogen structure are carbon $(\mathrm{C})$, hydrogen $(\mathrm{H})$, oxygen $(\mathrm{O})$, nitrogen $(\mathrm{N})$, and sulphur $(\mathrm{S})$. According to Akash and Jaber [8] oil shale kerogen may have molecular weight in the order of 3000, with an approximate empirical formula $\mathrm{C}_{200} \mathrm{H}_{3000} \mathrm{SN}_{5} \mathrm{O}_{11}$ and $\mathrm{C} / \mathrm{H}$ ratio about 1.5 . kerogen is derived from different sources so it usually has highly variable structure and may reach up to $50 \%$ of oil shale

\footnotetext{
*Address correspondence to this author at the Department of Mining Engineering, Al-Hussein Bin Talal University -Jordan;

Tel:+962799249604; Fax :+96232179050;

E-mails: salah.thyabat@ahu.edu.jo and althyabat@yahoo.co.uk
}

matrix weight [9]. Abed and Arouri [10] divided oil shale into three types according to the relation between their $\mathrm{H} / \mathrm{C}$ and $\mathrm{O} / \mathrm{C}$ ratios as shown in Fig. (1). Higher $\mathrm{H} / \mathrm{C}$ ratio means higher oil yield while higher $\mathrm{O} / \mathrm{C}$ ratio translated into higher calorific value. Therefore, Type 1 oil shale is more suitable for pyrolysis/ retorting while type 3 oil shale is more suitable for direct combustion.

According to Tissot and Welte [11], oil shale organic components are divided into two parts: bitumen and kerogen. In some oil shales, the organic matter is amorphous (bituminite) and is likely a mixture of degraded algae or bacterial remains. Generally, the organic matter in oil shale consists of remains of algae, spores, pollen, plant cuticle and corky fragments of herbaceous and woody plants, and other cellular remains of lacustrine, marine, and land plants [12].

On the other hand, inorganic minerals associated with oil shale depend on the origin of these deposits. They are mainly carbonates (calcite, dolomite), quartz, clay (kaolinite, smectite, illite), and small amounts of pyrite. Generally, oil shale kerogen is found as fine grains $(<20 \mu m)$ that encapsulated within these inorganic minerals as shown in Fig. (2).

The relation between organic and inorganic matter must be considered in the selection of any oil shale recovery techniques. For example, organic matter in Jordanian oil shale is found as black branches dispersed in the matrix, and as oil drops filling the formation cavities. Therefore, organic matter liberation requires extensive grinding $(<20 \mu \mathrm{m})$ which is very expensive. kerogen (organic carbon) can be 
estimated from the measurement of total carbon including the carbon of carbonates in oil shale matrix. Fig. (3) shows the relation between organic and inorganics in oil shale. Tsai and Lumpkin [6] developed the following equation (Equation 1) to estimate organic carbon in Colorado oil shale matrix.

\section{Organic Carbon $(w t \%)=1.244 \times($ Total Carbon (wt\%) - Carbonate Carbon(wt\%))}

On the other hand, organic matter in some oil shale deposits is concentrated in coarser size fraction which facilitate their separation. El-Rahman and Al-Wakeel [14] found that $60 \%-80 \%$ of the Egyptian oil shale kerogen was concentrated in the $-53 \mu \mathrm{m}$ size fraction. Therefore attrition, scrubbing followed by classification was able to separate $35 \%-40 \%$ of their organic matter.

Using run of mine(ROM) oil shale directly in retorting or direct combustion affect the efficiency of organic matter conversion process and may create environmental and economic problems [15, 16]. Atwood [17] reported that oil shale carbonates (calcite, dolomite) decompose during retorting. Carbonates decomposition is endothermic which consumes process heat and releases $\mathrm{CO}_{2}$ with less heating value.

Zhirjakove [18] summarised the ecological issues that need to be considered in using any oil shale utilization technology as follows:
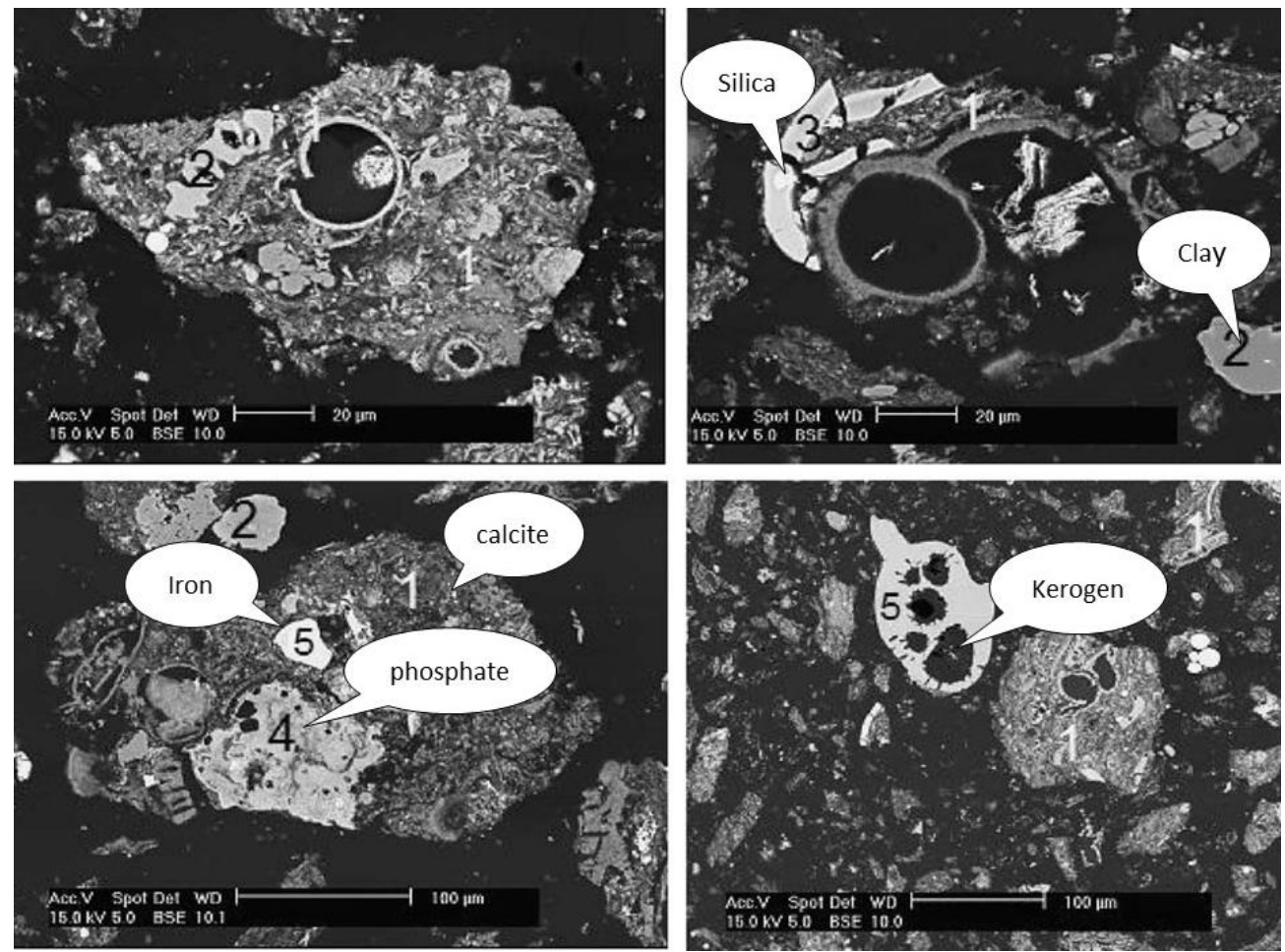

Fig. (1). Characterization of oil shale kerogen according to their C, H, O, content [10].

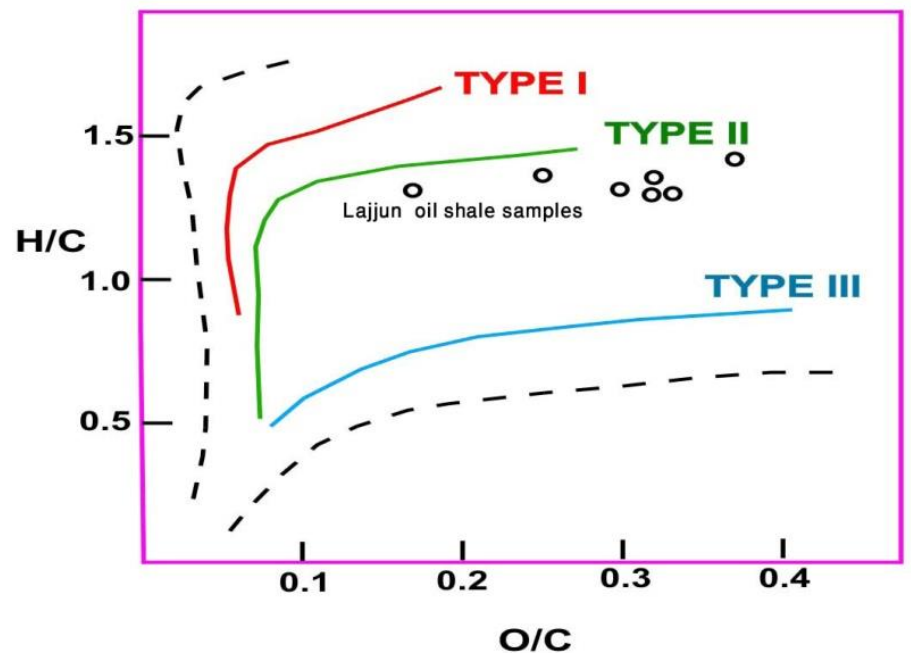

Fig. (2). SEM image of Jordanian oil shale [13]. 


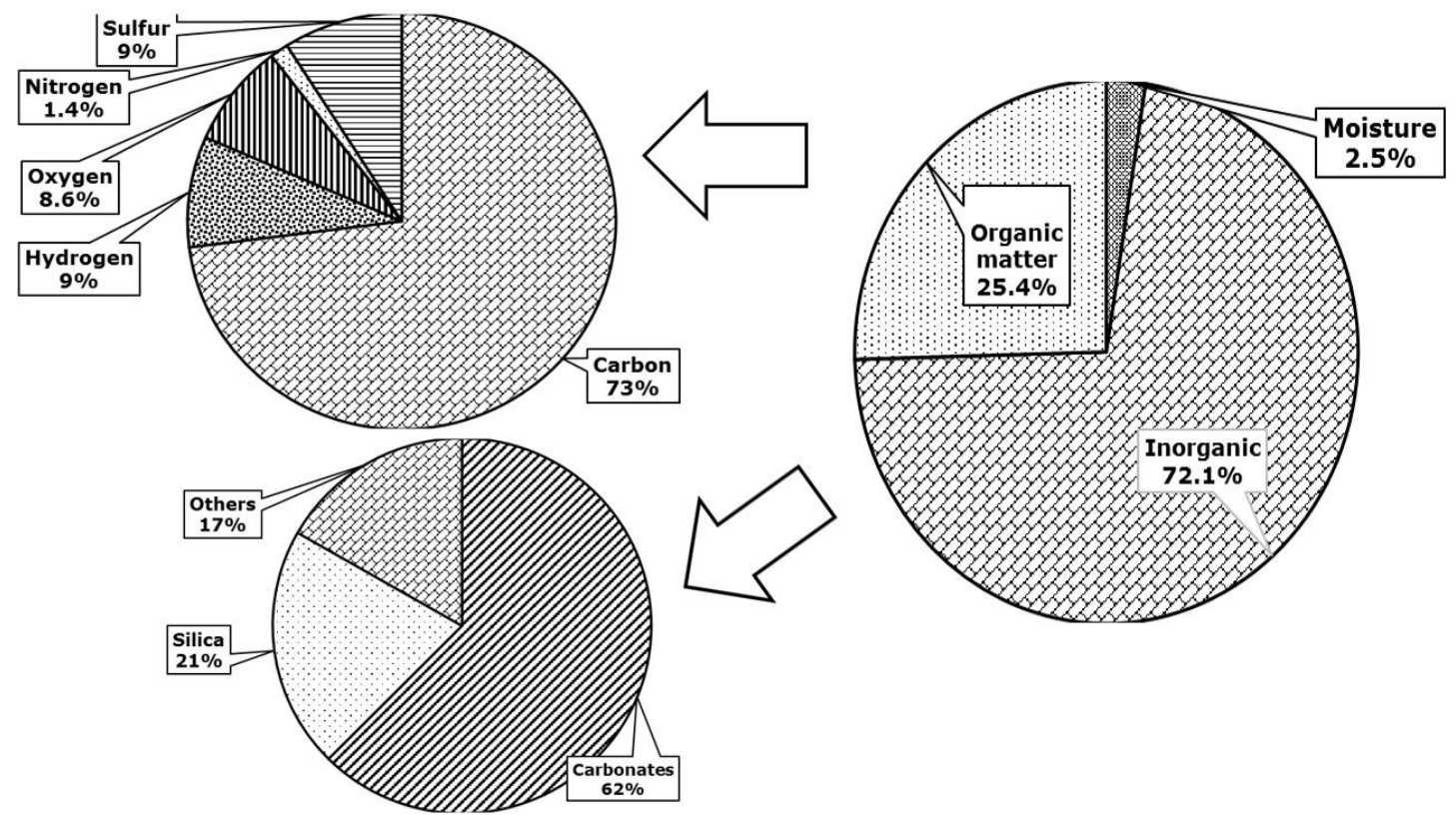

Fig. (3). Organic and inorganic composition of oil shale [7].

- Quantity of waste (solid, liquid, gas) produced by the process.

- Concentration of hazards and harmful substances in the process waste.

- Ecological mobility of elements contained in the waste

- Availability of practical methods to protect the environment from harmful substances in the waste.

- Consumption of natural resources (water, air, soil) for processing technology.

Since oil shale deposits vary significantly in their grade, physical, and chemical properties. Pre- concentration (beneficiation) of oil shale matrix before it can be used in retorting or direct combustion is economically important. According to Moudgil and Arbiter [19] pre-concentration techniques can be categorised into two types based on the size of oil shale particles:

- Techniques suitable for coarse particles: crushing and screening, sorting, and gravity separation.

- Techniques suitable for fine particles: froth flotation, selective flocculation, and oil agglomeration.

While, the advantages of oil shale beneficiation can be summarised as follows [19]:

- Beneficiation reduce the cost of material handling and waste disposal. Tsai and Lumpkin [6] reported that using froth flotation reduced oil shale matrix by $50 \% \mathrm{wt}$ with only $20 \%-25 \%$ of organic carbon losses.

- Allow the recovery of oil /energy from low grade oil shale by retorting or direct combustion. Flotation improved Colorado oil yield from $117 \mathrm{~L} /$ tonne to 175 L/tonne with approximately $80 \%$ organic carbon recovery [6].

- Improve the thermal efficiency /caloric value of the retorted /burned oil shale.
- And beneficiation allow the utilization of the inorganic and heavy minerals associated with oil shale.

Oil shale beneficiation by froth flotation hasn't received enough attention in the last two decades. The main reason was the cost of the process since flotation requires extensive grinding to liberate oil shale kerogen. However, the recent surge in oil price, the development of fine grinding technologies, may improve the efficiency of oil shale beneficiation by froth flotation. The advantages of using froth flotation may include improving pyrolysis kinetics, chemical reactivity, and saving energy by rejecting most of the inorganic gangue in oil shale matrix [14].

In this review, previous work on oil shale concentration by froth flotation will be critically reviewed. The aim was to shed some light on this obsolete subject and to encourage researchers to utilize the recent advances in grinding and flotation technologies in order to develop new economic and environmental friendly methodologies to beneficiate oil shale.

\section{FROTH FLOTATION}

Froth flotation is the most popular beneficiation process in minerals industry. This may be due to its high efficiency and relatively low cost. It also has some applications in other fields such as paper deinking and wastewater treatment [2029]

The main principle of froth flotation relies on the differences in physiochemical properties of particles. In flotation, the differences in interfacial tension between phases (liquid, gas, solid) is utilized to selectively separate valuable minerals particles i.e kerogen particles in the case of oil shale.

However, the major limitations of using froth flotation in oil shale beneficiation are the extensive energy required to grind oil shale matrix to liberate kerogen and then pelletizing 
the concentrate before it can be retorted or directly burned [30]

\subsection{Mechanical Flotation}

Most of oil shale flotation was conducted by conventional mechanical flotation cell using non-ionic collector such as kerosene. Fahlstrom [31] used Amyl Alcohol to float Swedish and USA oil shale. He added the collector into the pebble mill where it ground $\left(\mathrm{P}_{80}=15 \mu \mathrm{m}\right)$ to liberate kerogen. Conducting flotation for 10 minutes at 5\%$15 \%$ solids, the author reported $90 \%$ Kerogen recovery and $50 \%$ concentrate grade.

Fig. (4) shows recovery - grade relationship as reported by Fahlstrom [31]. The figure shows that a concentrate of 50 $\%$ kerogen can be obtained from oil shale matrix contain 5\% kerogen with $95 \%$ kerogen recovery. On the other hand, the removal of ash forming minerals in oil shale matrix exponentially reduced with increasing oil shale kerogen as shown in Fig. (5). Almost 95\% of ash forming minerals were removed to obtain a concentrate assaying $50 \%$ kerogen with $95 \%$ recovery from a feed contain 5\% kerogen compared to approximately $70 \%$ concentrate grade when a feed contain $25 \%$ kerogen was used. This indicates that flotation was more effective for low grade oil shale .i.e. enrichment ratio is approximately three times higher for low grade oil shale.

Tsai and Lumpkin [6] studied the effect of some operating parameters (feed size, collector, and frother type and dosages) on the flotation performance of USA oil shale using factorial experimental design. The authors reported that a concentrate of $75 \%$ kerogen and $175 \mathrm{~L} /$ tonne oil yield can be obtained from a flotation feed contains $16 \%$ kerogen and $117 \mathrm{~L} /$ tonne (fisher assay) with $75 \%$ organic matter recovery.

The effect of collector dosage and particle size on oil shale flotation is shown in Fig. (6). For fine size fraction $(-150+75 \mu \mathrm{m})$, the percentage of oil shale matrix floated is exponentially increased with collector dosage before it reaches a plateau of $80 \%$. Similarly, coarse size fraction $(-500+250 \mu \mathrm{m})$ has the same trend but with lower plateau $(25 \%)$. this may be due to the difference in specific gravity

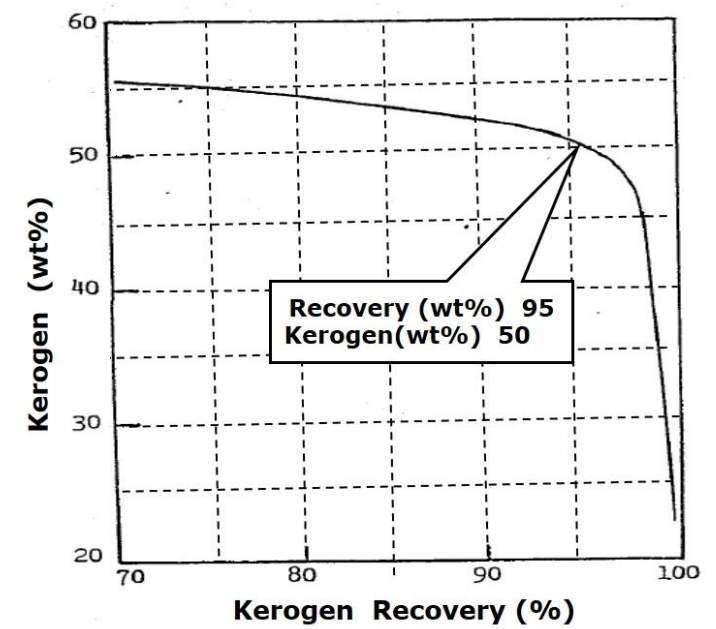

Fig. (4). The recovery - grade relationship for oil shale flotation [modified from Fahlstrom [31]].

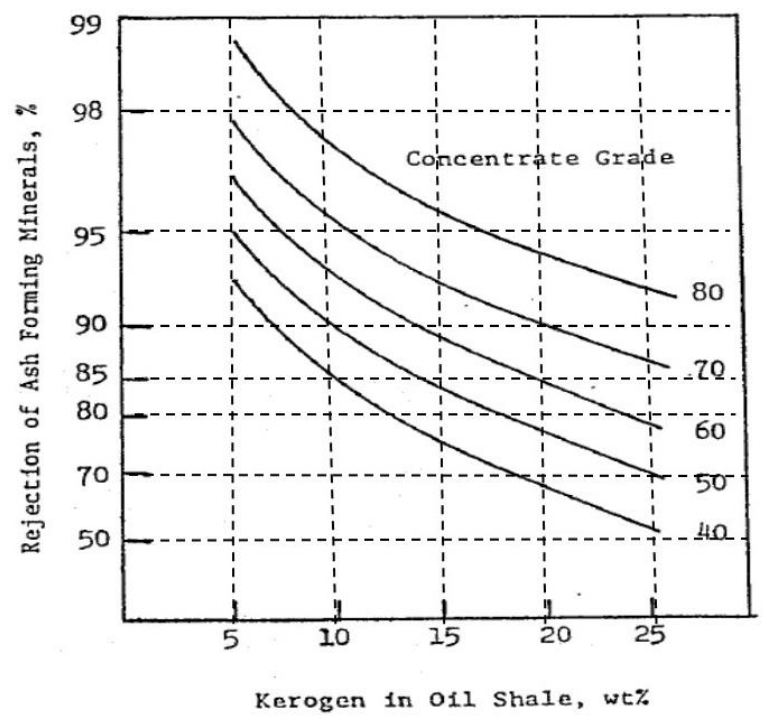

Fig. (5). The effect of kerogen concentration on oil shale matrix beneficiation (ash minerals =total minerals-carbonate minerals)[modified from [31]].

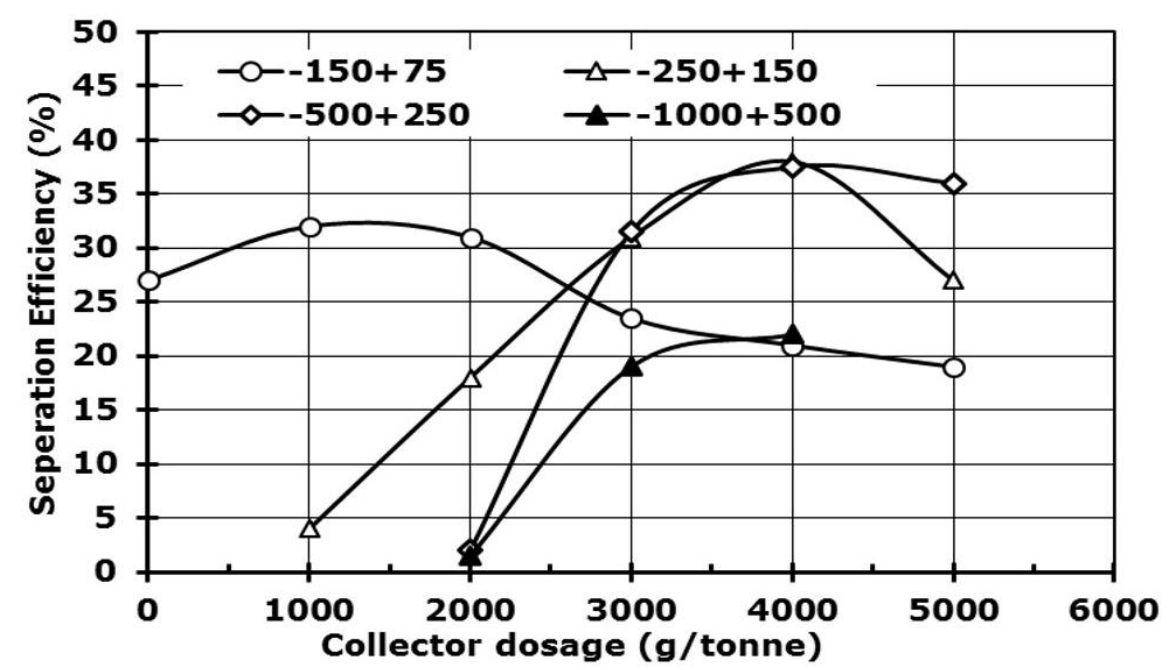

Fig. (6). Effect of collector dosage on USA oil shale froth flotation [modified from [6]]. 
of oil shale kerogen and the associated inorganic minerals which makes the maximum floatable kerogen particle size larger than minerals particles [6].

A comparison between separation efficiency of organic carbon (Equation 2) at different size fractions as illustrated in Fig. (7), showed that the highest separation efficiency was obtained when $-500+250 \mu \mathrm{m}$ size fraction was floated by $4000 \mathrm{~g} /$ tonne collector dosage. This indicates that this size fraction is the optimum size where the selectively between organic and inorganic fractions was maximized

$S E=\left(\boldsymbol{\eta}_{\text {organic recovery }} \times \boldsymbol{\eta}_{\text {Minerals rejection }}\right) \times 100 \%$

Tippen and Rex [7] investigated the effect of concentrating shale by froth flotation on the hydroretorting (using hydrogen rich gas during retorting) performance. Flotation tests were conducted in Denver flotation cell using $500 \mathrm{~g}$ shale at $50 \%$ solids. Flotation feed was ground in a rod mill ( $50 \%$ solid) for two hours to reduce particle size to $\mathrm{P}_{90}=10$ micron .Flotation tests results showed that oil content in the flotation concentrate was increased by a factor of 2-3 while oil bench scale hydroretorting was increase by a factor of 2-5.5. The average combustible recovery was found to be higher than $90 \%$ while more than $80 \%$ of the oil in the feed was recovered.

Fig. (8) visualize the response of different types of oil shale to flotation. Apart from Canadian oil shale, the losses in organic matter due to flotation ranges from $10 \%-20 \%$ but improvement in oil content was significantly increased by $210 \%$ and $70 \%$ for Alabama and Brazilian oil shale, respectively. This indicates that the characteristics of the organic matter in the oil shale and the associated inorganic minerals play a major role in determining the amenability of oil shale for flotation.

Austin and Willington [32] compared the effect of oil shale grinding on flotation performance. Chinese oil shale was ground by ball and hammer mill for different time intervals then floated in Denver flotation cell by fuel oil and

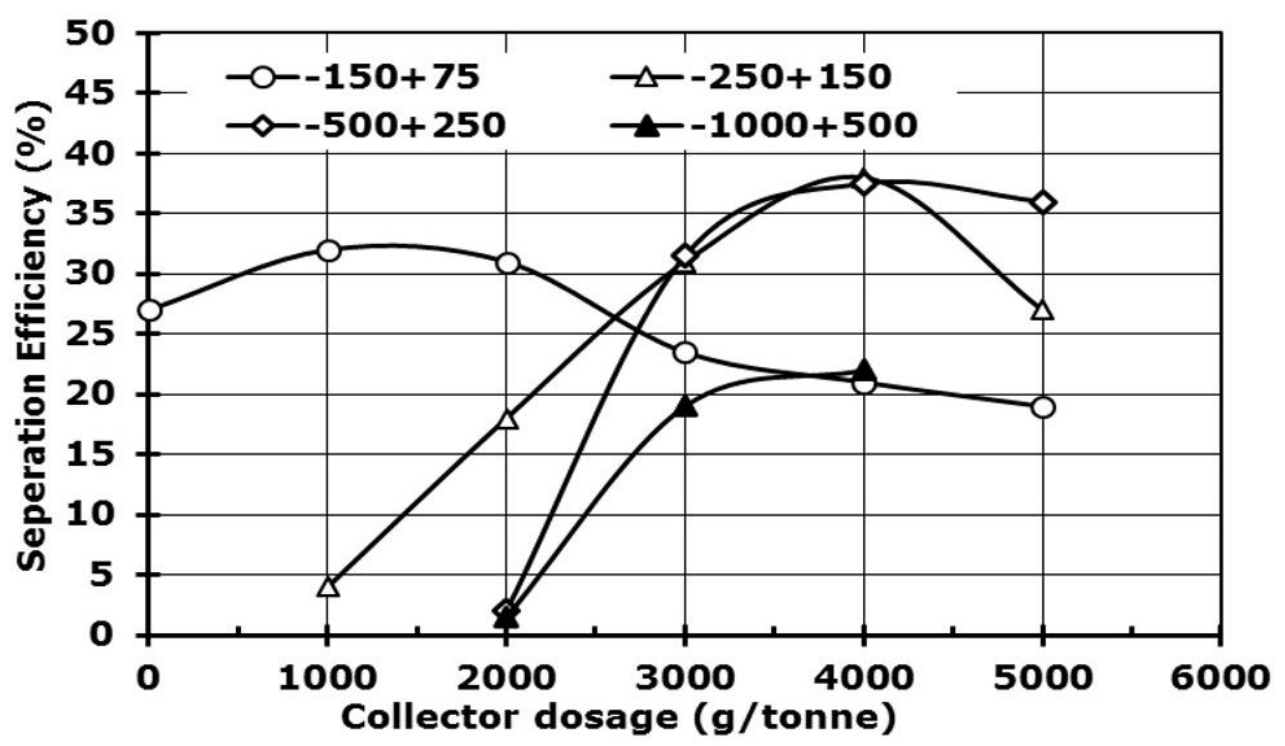

Fig. (7). Effect of particle size on separation Efficiency (SE) of USA oil shale froth flotation [modified from [6]].

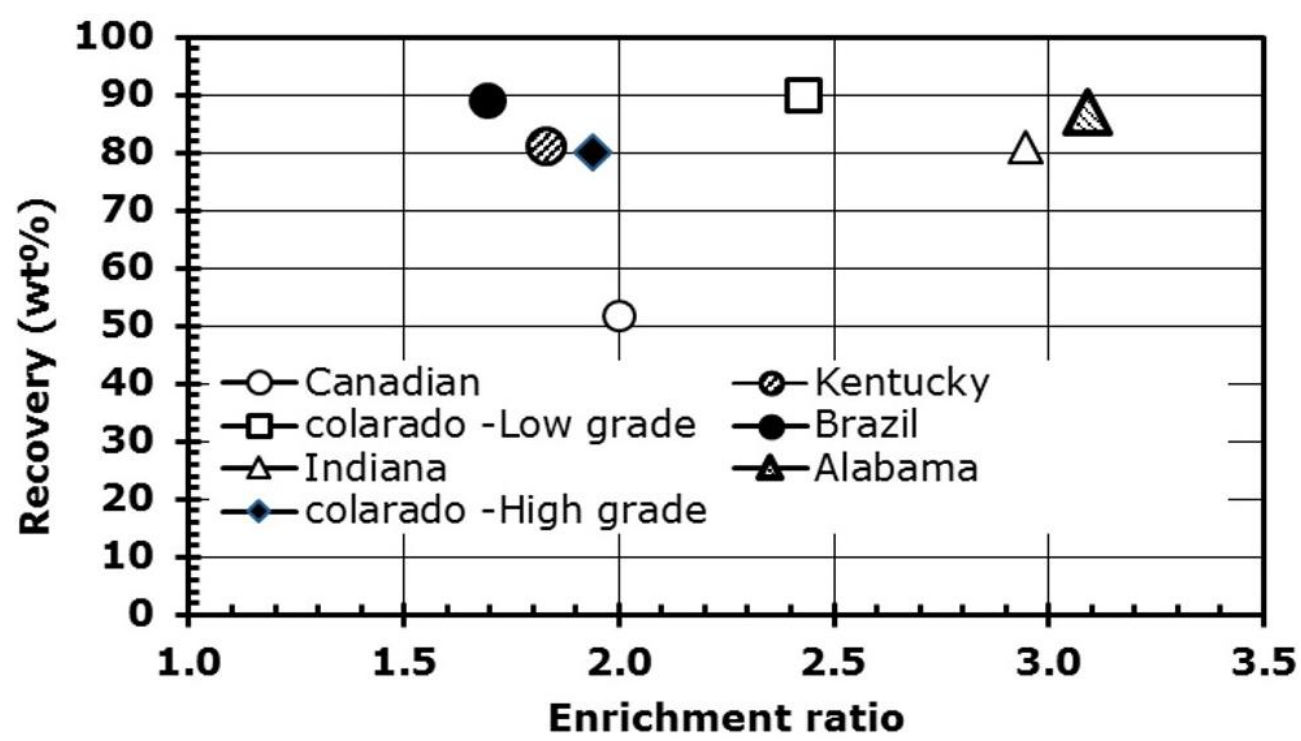

Fig. (8). Amenability of oil shale for froth flotation [modified from [7]]. 
Teric 401 as collector and frother, respectively. As shown in Fig. (9), a linear relationship was observed between both oil yield (L/tonne) and ash (inorganic) distribution in flotation concentrate and size distribution of flotation feed; the finer the feed the higher oil yield and ash rejection from flotation concentrate. These results confirm the importance of fine grinding of oil shale before it can be successfully beneficiated by froth flotation.

Audeh [33] suggested a method for oil shale flotation while avoiding fine grinding of oil shale matrix. He used water circulation as the main source for size reduction based on the assumption that oil shale particles crumble in water and lose their size and shape. In Audeh study, $10 \%$ solids of oil shale slurry $(<2.36 \mathrm{~mm})$ was circulated for approximately 30-60 minutes. Then ( $2 \mathrm{~kg} /$ tonne) of sodium dodecyl benzene sulfonate (SDBS) was added to the slurry and recirculated for further 10 minutes. Compressed air was then introduced and froth formed at the top of the cell which continuously removed in predetermined time intervals. Unfortunately, Flotation results and Fischer assay of the concentrated shale was not promising due to insufficient grinding (liberation) of the shale kerogen.

El-Rahman and Al-Wakeel [14] used froth flotation to concentrate Kerogen from Egyptian oil shale. Flotation feed was conditioned using different dosage of collector (kerosene) at $50 \%$ solids for 5 minutes. Then flotation was conducted at natural $\mathrm{pH}$ and $20 \%$ solids for 9 minutes. The results showed that at neutral $\mathrm{pH}$ and high collector dosage $(6.4 \mathrm{~kg} /$ tonne $)$, organic matter was increased by $50 \%$ with approximately $65 \%$ recovery.

Recently, Altun et al [34, 35] studied the upgrading of Turkish oil shale by froth flotation for possible use as solid fuel. The authors tested several types of collectors at different operating parameters such as collector and frother dosage, and pulp $\mathrm{pH}$. The optimum flotation results were obtained when oil shale was upgraded by reverse flotation at natural $\mathrm{pH}$. However, the authors reported that different types of oil shale has different response to reverse flotation. Oil shale ash was reduced by approximately $30 \%-50 \%$ while organic matter recovery ranging from $58 \%$ to $84 \%$. According to the authors, low flotation response may be due to the poor floatability of oil shale organic matter and the nature of associated gangue (carbonate, silica, and pyrite).

Most Recently, Al-Ottoom [36] studied the floatability of El-Lajjuon /Jordan oil shale by Denver D-12 flotation cell. The author used factorial experimental design to evaluate the effect of particle size, collector /frother ratio, and slurry $\mathrm{pH}$. Different types of collector were evaluated such as kerosene, DMSO, calcium Lignosulfonate, sodium ligno-sulfonate, sulphonated naphthalene, diethyl ketone, and fuel oil. The author found poor recovery of oil-rich components with a maximum of $3 \%$ enhancement when using fuel oil \#2 as a collector. According to the author, this may be due to the wetting effect of kerogen during grinding to the associated gangue minerals which make them hydrophobic and reduce their flotation selectivity.

In another work which may be not directly related to oil shale flotation, Vadovic [37] used heavy media (sink/float) separation method to concentrate USA eastern oil shale. Fine shale was mixed with brine solutions containing calcium chloride or calcium bromide with densities in the range between $1.05-1.64 \mathrm{~g} / \mathrm{ml}$. The author showed that by using a brine solution with density $1.105 \mathrm{~g} / \mathrm{ml}$, organic carbon was increased from $12.83 \%$ to $18.10 \%$. No recovery results were reported by the author.

\section{COLUMN FLOTATION}

The majority of oil shale flotation work found in the literature were conducted by conventional mechanical flotation cell. This may be due to the available flotation technologies and machines in 1980s. However, the use of column flotation in minerals industry gained momentum since 1990s. It replaced the conventional mechanical flotation cells especially in flotation cleaning circuits. The main advantages of column flotation are [38-42]:

- Cleaner concentrate.

- Less energy consumption due to less mechanical parts.

- Less maintenance costs.

- Higher capacity to size ratio i.e. less capital costs.

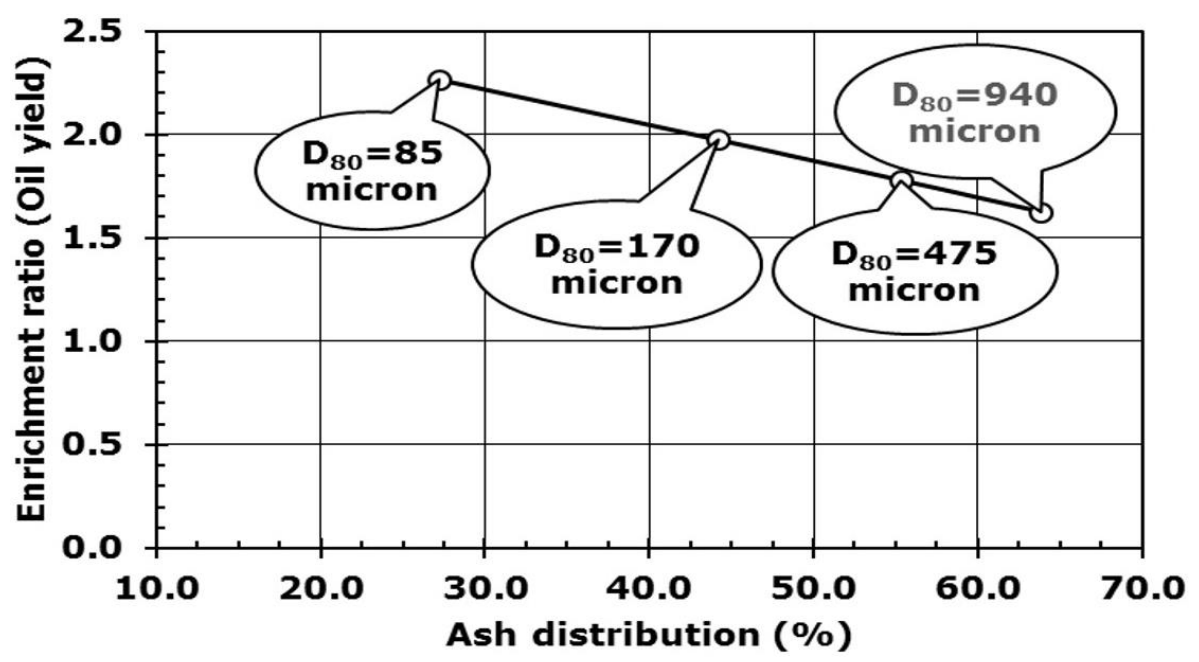

Fig. (9). Amenability of oil shale for froth flotation [modified from [32]]. 
However, there were a few attempts to beneficiate oil shale by column flotation. Schultz et al [43] used column flotation shown in Fig. (10) to evaluate the effect of three operating parameters on the flotation of Alabama oil shale. They studied the effect of bubble size (sparger pore size), feed solids percent, air flow rate, wash water flow rate, and frother and dispersant dosages on the grade of oil shale (\% carbon ) and the oil yield . A summary of Schultz results is presented in Fig. (11) and Table 1.

As shown in the figure, the optimum operating parameters which gave the maximum oil yield and separation efficiency was achieved at Test E. At these operating parameters the oil yield was increased by approximately $215 \%$ and carbon enrichment ratio was approximately 2.8. Comparing Test $\mathrm{E}$ and Test $\mathrm{C}$ shows that increasing frother dosage increased separation efficiency but slightly reduced oil yield. This may be due to increasing flotation selectively of kerogen due to creation of finer bubble size (larger surface area) and more stable froth. However, increasing finer kerogen particles in the concentrate may have a negative effect on the oil shale retorting which reduced oil yield.

Fig. (11) also showed that increasing solids percentage had a deteriorating effect on both separation efficiency and oil yield. Increasing solid percentage from $3 \%$ (Test $\mathrm{C}$ ) to $7 \%$ (Test B) reduced separation efficiency and oil yield by $35 \%$ and $7 \%$, respectively while concentrate grade was reduced from $45.73 \%$ to $42.74 \%$. This may be due to the reduction in selectivity due to increasing pulp density which increased non selective solids entrainment and bubblesparticles detachments.

However, increasing solid percentage and bubble size simultaneously, significantly reduced separation efficiency but slightly increased oil yield. Increasing solid percentage from 3 (Test C) to $7 \%$ (Test D) and sparger pore size from 15 to 85 micron reduced separation efficiency from $62.1 \%$ to $52.8 \%$ and increased oil yield from 162.8 to $165.3 \mathrm{~L} /$ tonne . This may be due to increased bubble size and generation of stable froth due to increasing pulp density which produced

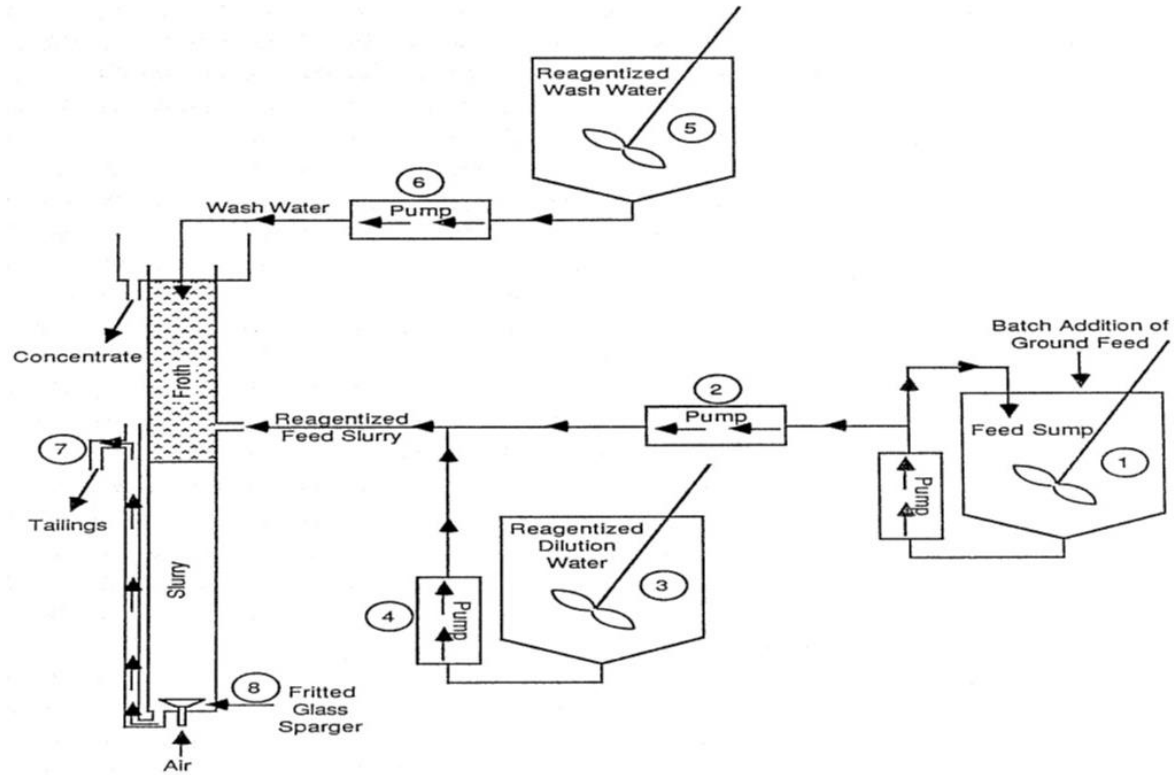

Fig. (10). Schematic diagram of a conventional column flotation cell [Schultz [43]].

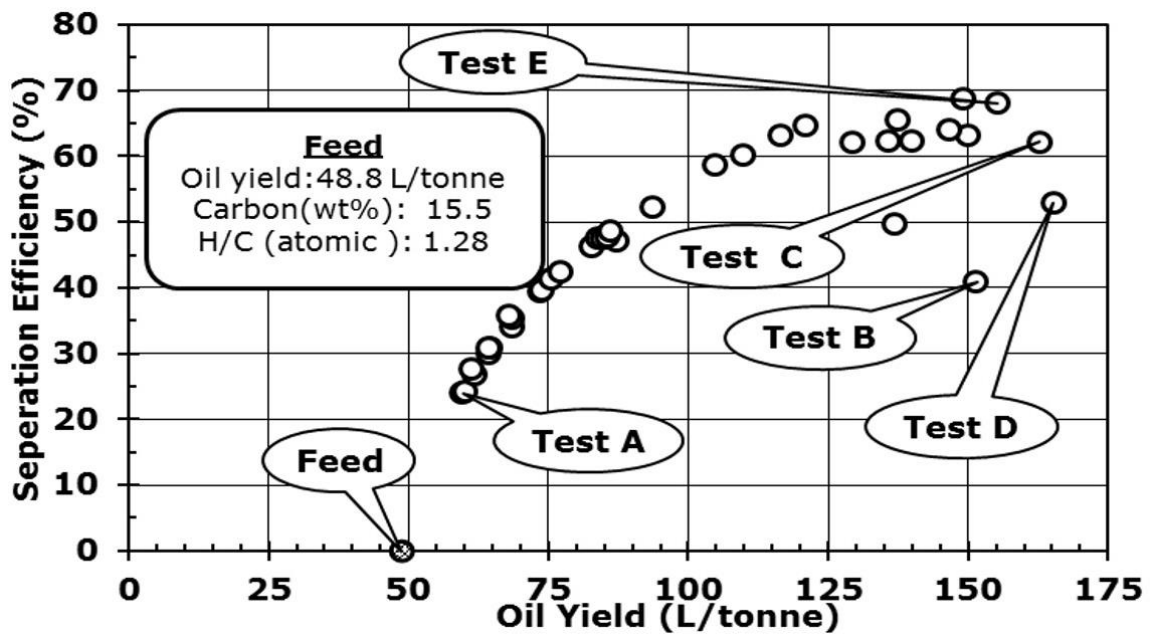

Fig. (11). Column flotation of oil shale results [modified from Schultz [43]]. 
cleaner concentrate. However, because kerogen particles are fine, increasing bubble size reduced surface area available for fine particle flotation which reduced kerogen recovery. At Test D the grade and kerogen recovery were $46.4 \%$ and $60.1 \%$, respectively compared to $45.72 \%$ and $73.8 \%$, respectively for Test $\mathrm{C}$.

Finally, a summary of oil shale flotation parameters used by several researchers is presented in Table 2 .

\section{ECONOMICS OF OIL SHALE FLOTATION}

To compare the effect of flotation on oil shale retorting economics, two scenarios were compared; the first scenario was to directly retort the crushed oil shale $(-125 \mathrm{~mm})$ without further grinding, while the second scenario was to use three stages of grinding to reduce particle size to $(-20$ $\mu \mathrm{m}$ ) then upgraded oil shale by froth flotation before retorting . A detailed description of these scenarios was reported by Weiss et al (30) while Fig. (12) is a schematic diagram of these scenarios.

Process costs shown in Table $\mathbf{3}$ are twice the cost reported by Weiss et al [30] assuming that the prices was doubled since 1981; the year of Weiss et al study. The table shows that beneficiation cost (fine grinding, flotation, and dewatering) was the reason for higher capital costs for concentrate retorting scenario. Capital cost for each tonne of

Table 1. Column flotation results of oil shale [modified from Schultz [43]].

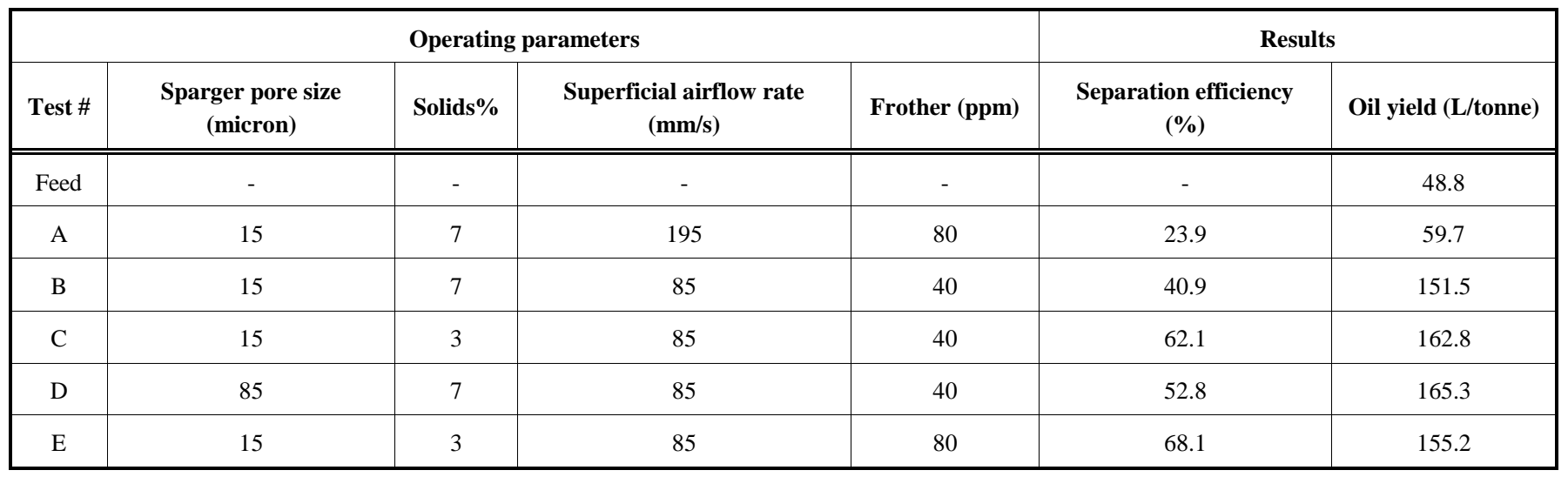

Table 2. A summary of flotation parameters used in oil shale flotation.

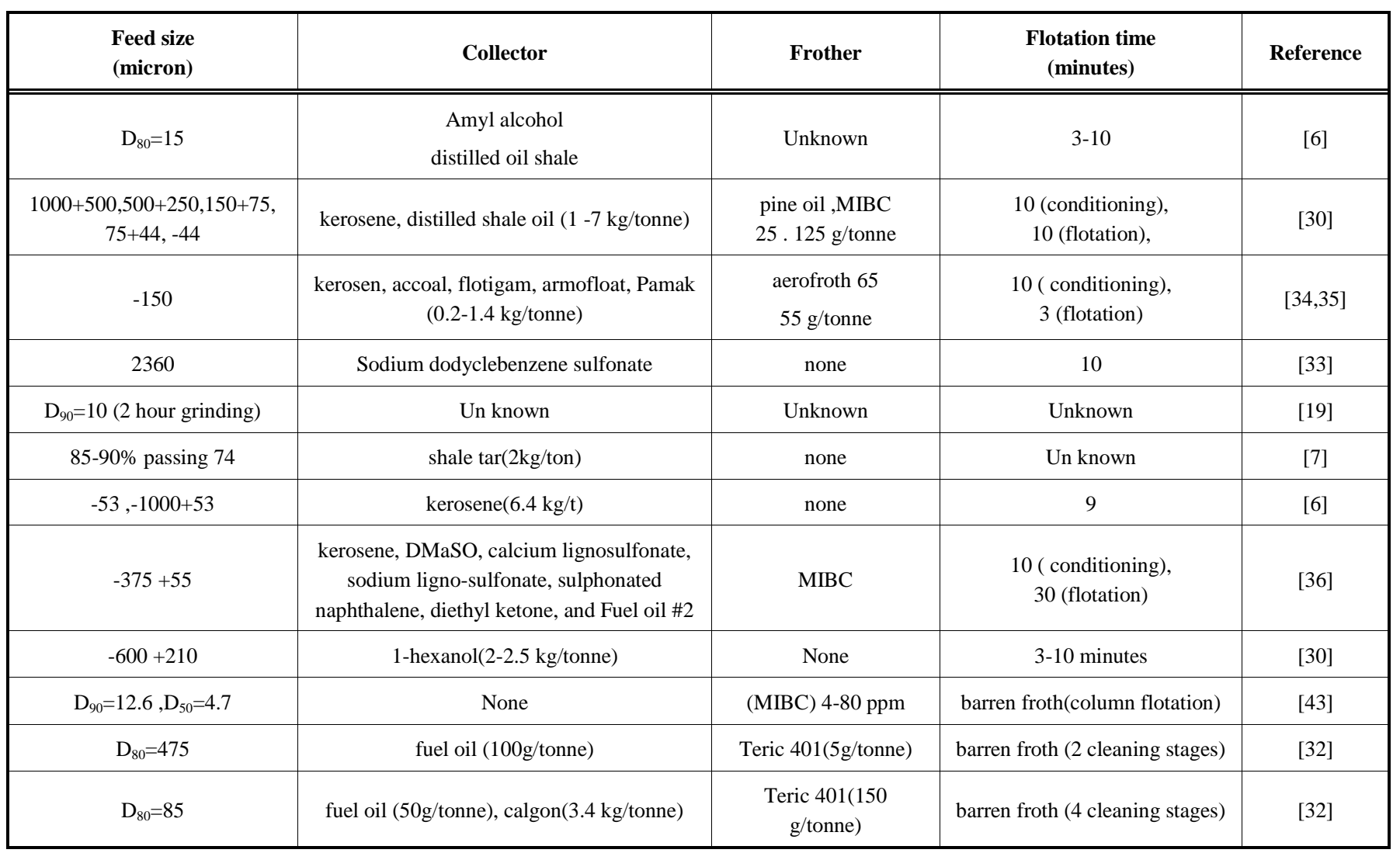


ROM shale was 29400 and $30100 \$$ for crushed oil shale and concentrate retorting, respectively. On the other hand the capital cost of pyrolysis and fractionation for the concentrate scenario was approximately $80 \%$ lower than crushed oil shale retorting scenario. This due to the reduction in oil shale tonnage need to be retorted; the feed for direct pyrolysis scenario was 72000 tonne/day compared to just only 19000 tonne/ day for concentrate retorting scenario. These results showed the positive effect of oil shale beneficiation on pyrolysis and fractionation economics. However, the higher cost of beneficiation especially fine grinding offset this advantage. Therefore any reduction in the beneficiation costs will significantly reduce the capital cost of oil shale concentrate pyrolysis scenario.

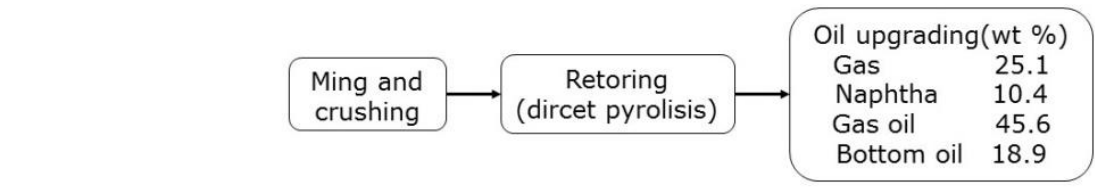

Scenario 1

$\begin{gathered}\text { Ming and } \\ \text { crushing }\end{gathered} \rightarrow \begin{gathered}\text { Beneficiation } \\ \text { (grinding ) }\end{gathered} \rightarrow \begin{gathered}\text { Beneficiation } \\ \text { (Flotation ) }\end{gathered} \rightarrow$ Beneficiation
(dewatering ) $\rightarrow$ Pyrolisis $\rightarrow \begin{array}{cc}\text { Oil upgrading(wt \%) } \\ \text { Gas } \\ \text { Naphtha } & 25.1 \\ \text { Gas oil } & 40.4 \\ \text { Bottom oil } & 18.6\end{array}$

\section{Scenario 2}

Fig. (12). Schematic diagram of an oil shale retorting scenarios [modified from Weiss et al. [30]].

Table 3. Economics of oil shale retorting scenarios (Weiss et al. [30]].

\begin{tabular}{|c|c|c|}
\hline $\begin{array}{c}\text { Costs } \\
\text { (\$/tonne ROM shale ) }\end{array}$ & \multicolumn{2}{|c|}{ Processing scenarios } \\
\hline \multicolumn{3}{|l|}{ A-Capital costs } \\
\hline Mining & 8000 & 8800 \\
\hline Beneficiation & 0 & 15200 \\
\hline Total capital cost & 29400 & 30100 \\
\hline Capital charges ( $25 \%$ capital) & 20.2 & 20.8 \\
\hline \multicolumn{3}{|l|}{ B-Running costs } \\
\hline Fuel & 2.3 & 0.9 \\
\hline Power & 0.03 & 0.008 \\
\hline water & 0.05 & 0.008 \\
\hline steam & 0.3 & -0.1 \\
\hline Chemicals & 0.08 & 0.08 \\
\hline Operating labor(OL) & 0.19 & 0.11 \\
\hline Supervision \& services $(40 \% \mathrm{OL})$ & 0.08 & 0.05 \\
\hline
\end{tabular}


On the other hand, comparing the running costs for the retorting scenarios shows that the cost of retorting one tonne of oil shale concentrate was almost 2 times higher than retorting one tonne of crushed ore ; the cost of concentrate retorting was $14.09 \$ /$ tonne while the cost of crushed ore retorting was 8.18 \$/tonne. As shown in Table 3 the reason was the higher cost of oil shale beneficiation. However, Weiss et al [30] didn't take into account the cost of spent shale disposal. Assuming that each tone of spent shale cost $10 \$$ for disposal, the total running costs of concentrate retorting will rise to 15.38 \$ compared to 15.99 \$ for crushed oil shale retorting. Also since the tonnage of crushed ore was approximately 3 times higher than concentrate tonnage, the capital costs for spent shale disposal will be also 3 times higher for crushed oil shale retorting scenario.

Finally, it can be concluded from previous discussion that oil shale concentrate retorting was more favourable than crushed shale retorting given that the cost of beneficiation was minimized and the cost of spent shale disposal (i.e environmental impact) was taken into account.

\section{CONCLUSIONS}

Based on the previous review, the following conclusions can be drawn:

- Oil shale is an energy resource which has wide distribution in many parts of the world. These deposits are quite variable in terms of their organic matter content and mineralogy. Most of oil shale deposits are not true shale but they are mainly organic rich carbonates which vary significantly in their grade, physical and chemical properties

- One of the major limitations of using froth flotation in oil shale beneficiation are the requirement of grinding oil shale for fine particle which require extensive amount of energy, and the requirement for pelletizing the concentrate to be retorted or directly burned.

- In order to liberate kerogen, oil shale is required to be ground to less than 20 micron. However, the selectivity of flotation may be reduced by the wetting effect of Kerogen during grinding where the associated gangue minerals become hydrophobic. This may be reduced by attrition and scrubbing of flotation pulp at high solids concentration.

- Most of oil shale flotation was conducted by the conventional mechanical flotation cell using non-ionic collector such as kerosene. But limited work reported in the literature showed the advantages of column flotation over mechanical flotation for fine Kerogen particles flotation.

- Flotation has more pronounced effect on low grade oil shale. Almost $95 \%$ of ash forming minerals were removed to obtain a concentrate assaying $50 \%$ kerogen with $95 \%$ recovery from a feed contain 5\% kerogen compared to approximately $70 \%$ concentrate grade when a feed contain $25 \%$ kerogen was used.

- Using flotation concentrate as a feed for hydroretorting (using hydrogen rich gas during retorting) performance increased oil yield by a factor of 2-5.5. The average combustible recovery was found to be higher than $90 \%$ while more than $80 \%$ of the oil in the feed was recovered.

- Capital cost of pyrolysis and fractionation for using flotation concentrate was approximately $80 \%$ lower than crushed oil shale retorting. This due to the reduction in oil shale tonnage need to be retorted; the feed for direct pyrolysis scenario was $275 \%$ lower than concentrate retorting scenario.

- Oil shale concentrate retorting was more favourable than crushed shale retorting given that the cost of beneficiation was minimized and the cost of spent shale disposal (i.e environmental impact) was taken into account.

\section{CONFLICT OF INTEREST}

The authors declare that there is no conflict of interest regarding the publication of this article.

\section{ACKNOWLEDGEMENTS}

None declared.

\section{REFERENCES}

[1] J.M. Hunt, Petroleum Geochemistry and Geology. WH Freeman: New York, 1996.

[2] A. Kennedy, Surface Mining, $2^{\text {nd }}$ ed. Society for Mining, Metallurgy and Exploration Inc: Jakarta, Indonesia, 1990.

[3] E. Eseme, J. Ural, B.M. Krooss, and R. Littke,'Review of mechanical properties of oil shale", Report , Estonia Academy publishers, Estonia, 2007.

[4] J.R. Dyni, "Geology and resources of some world oil-shale deposits", Report, U.S. Geological Survey, USA, 2005.

[5] W.Youngquist, "Shale Oil: The elusive energy", Report, Hubbert center Newsletter, USA, 1997.

[6] S. C. Tsai, and R. E. Lumpkin, "oil shale beneficiation by froth flotation", Fuel, vol. 63, no.4, pp. 435-439, 1984.

[7] R. B. Tippin, and R. C. Rex, "combined beneficiation and retorting of oil shale", In: Symposium on Oil Shale Reactivity and Processing, Chicago, 1985.

[8] B. A. Akash, and J. O. Jaber, "Characterization of shale oil as compared to crude oil and some refined petroleum products", Energy Sources, vol. 25,pp. 1171-1182,2003.

[9] E. Easac, "A study on the EU oil shale industry - viewed in the light of the Estonian experience", Report, Committee on Industry, Research and Energy of the European Parliament, 2007.

[10] A. M. Abed, and K. Arouri, "Characterization and genesis of oil shales from Jordan, In: International Conference on Oils Shale, recent trends in Oil Shale, 2006, rtos-A121.

[11] B.P.Tissot, and D. H. Welte, Petroleum Formation and Occurrence, $2^{\text {nd }}$ ed. Springer-Verlag: USA 1984.

[12] J.R. Dyni, "Geology and resources of some world oil-shale deposits", Report, U.S. Geological Survey, 2006.

[13] A. Y. Al-Otoom, R. A. Shawabkeh, A. M. Al-Harahsheh, and A. T. Shawaqfeh, "the chemistry of minerals obtained from the combustion of Jordanian oil shale”, Energy, vol 30 ,pp.611619,2005 .

[14] M .K. Abd El-Rahman and M.I. Al-Wakeel, "Enrichment of organic matter of some Egyptian black shales", Mineral Processing and Extractive Metallurgy, vol. 116, no. 3, pp.189-196, 2007.

[15] K. M. Ibrahim, and J. O. Jaber, "Geochemistry and environmental impacts of retorted oil shale from Jordan", Environmental Geology, vol. 52, pp.979-985, 2007.

[16] I. Kamenev, R, Munter, L. Pikkov, and L. Kekisheva, "Wastewater treatment in oil shale chemical industry", Oil Shale, vol.20,no.4, pp 443-457,2003.

[17] M. T. Atwood, "Integrating of large scale retorting operations with laboratory testing and analysis", In: $26^{\text {th }}$ oil shale symposium, 2006. 
[18] Y. Zhirjakove, "Ecological aspects of oil shale processing", In: 26 oil shale symposium, 2006.

[19] B. M. Moudgil, and N. Arbiter, "Oil shale beneficiation for above ground retorting", Mining Engineering, vol. 9, pp.1336-1338, 1982.

[20] R. Rodrigues, and J. Rubio, "DAF -dissolved air flotation: Potential applications in the mining and mineral processing industry", International Journal of Mineral Processing, vol. 82, no.1, pp.113, 2007.

[21] S. Mathur, "Kaolin flotation", Journal of Colloid and Interface Science, vol. 1, pp. 153-158, 2005.

[22] C. Perucca, "Potash processing in Saskatchewan - A review of process technologies", Clim Bull, vol.96, no.1070, pp. 61-65, 2003.

[23] N. Fraunholcz, "Separation of waste plastics by froth flotation - a review, part I", Minerals Engineering, vol. 17, no. 2, pp. 261-268, 2004.

[24] K. Theander, and R. J. Pugh, "Surface chemicals concepts of flotation de-inking", Colloids and Surfaces A-Physicochemical and Engineering Aspects, vol. 20, no.1-3, pp. 111-130, 2004.

[25] H. Alter, "The recovery of plastics from waste with reference to froth flotation", Resources Conservation and Recycling, vol.43, no.2, pp.119-132, 2005.

[26] Q. Min, Y. Y. Duan, and X.F. Peng, "Froth flotation of mineral particles mechanism", Drying Technology, vol.26, no. 8, pp.985995, 2008.

[27] S. Al-Thyabat, "Statistical evaluation of conditioning time and slurry concentration in the flotation performance of siliceous phosphate", Minerals and Metallurgical Processing, vol. 25, no.3, pp. 123:129, 2008.

[28] S. Al-Thyabat, "Optimization of phosphate flotation by using neural network", Journal of China University of Mining and Technology (JCMUT), vol.18, no.3, pp. 418-426, 2008.

[29] Al-Zoubi, Al-Thyabat, and Al-khateeb, "A hybrid flotationmembrane process for wastewater treatment: an overview", Desalination and Water Treatment, vol. 7, pp.60-70, 2009.

[30] M. A. Weiss, I.V. Klumpar, T. A. Ring, and C. R. Peterson, "shale beneficiation and oil recovery from the concentrate", Engineering Costs and Production Economics, vol.13, pp.135-154, 1988.

[31] P.H. Fahlstrom, "physical concentration route in oil shale wining", In: $12^{\text {th }}$ oil shale Symposium Proceedings, 1979, pp. 252-277.
[32] K. Austin, and H. Wellington, "A production of concentrate from oil shale at china Flat", Report no.TR20, Endeavour Oil Company, 1975.

[33] C. A. Audeh,"beneficiation of water-sensitive eastern oil shales", in: Symposium on Chemistry and Processing Supercritical Fluids, Chicago, 1985, pp 229-236.

[34] N. Altun, C. Hicyilmaz, J. Hwang, and A. Bagci, "Evaluation of a Turkish low quality oil shale by flotation as a clean energy source: Material characterization and determination of flotation behaviour", Fuel Processing Technology, vol.87, pp.783-791, 2006.

[35] N. Altun, C. Hicyilmaz, J. Hwang, and A. Bagci, "Beneficiation of Himmetoglu Oil Shale by Flotation as a Solid Fuel Substitute. Part 2: Process optimization by statistical technique", Energy and Fuels, vol. 20, pp.222-226, 2006.

[36] A. Y. Al-Otoom, an investigation into beneficiation of Jordanian El-Lajjun oil shale by froth floatation, oil shale 25 (2008) 247-253.

[37] C. J. Vadovic, "geochemistry and chemistry of oil shales", In: ACS Symposium Series no.230, 1983, pp.385-396.

[38] L. V. Lovachenok, "Rate of mineralization of air bubbles during flotation of oil shale Kerogen", Journal of Applied Chemistry of USSR, vol. 53,pp. 1171-1174,1981.

[39] J. A. Finch, and G.S. Doby, "column flotation: A selected review Part V", International Journal of Minerals Processing, vol. 33, pp.343-347, 1991.

[40] D. Tao, G. H. Luttrell, and R.H Yoon, "A parametric study of froth stability and its effect on column flotation of fine particles", International Journal of Minerals Processing, vol. 59, pp. 25-43, 2000.

[41] M. Yahyaei, S. Banisi, and H. Javani,"Replacing Mechanical Flotation Cells by a Flotation Column at the Pilot Plant of the Sarcheshmeh Copper Mine", Separation Science and Technology, vol. 41,pp.3609-3617, 2006.

[42] M.S. Jena, S.K. Biswal, S.P. Das, and P.S. Reddy, "Comparative study of the performance of conventional and column flotation when treating coking coal fines", Fuel Processing Technology, vol.89, no.12, pp.1409-1415, 2008.

[43] C.W. Schultz, J. Bates, and M. Misra , "Column flotation of eastern oil shale", Report no.89196, Minerals Resources institute, the University of Alabama, 1988.

Received: June 11, 2014

Revised: August 28, 2014

Accepted: September 03, 2014

(c) Al-Thyabat et al.; Licensee Bentham Open.

This is an open access article licensed under the terms of the Creative Commons Attribution Non-Commercial License (http://creativecommons.org/licenses/ by-nc/3.0/) which permits unrestricted, non-commercial use, distribution and reproduction in any medium, provided the work is properly cited. 